JIP, Vol.8, No. 1, Edisi Januari 2018, Hal: 40-52

Sabitul Kirom

\title{
Penguatan Karakter Diri Melalui Pembelajaran Drama Berbasis Kearifan Lokal Pada Mahasiswa
}

\author{
Sabitul Kirom \\ Universitas Islam Balitar \\ sabitulkirom@gmail.com
}

\begin{abstract}
Abstrak
Penelitian ini mendeskripsikan tentang penguatan karakter diri melalui pembelajaran drama yang berbasis kearifan lokal pada mahasiswa yang terfokus pada (1) perancangan pembelajaran dan (2) penerapan pembelajaran drama yang berbasis kearifan lokal untuk penguatan karakter pada mahasiswa. Penelitian ini termasuk ke dalam penelitian deskriptif kualitatif. Hasil penelitian ini yaitu perancangan pembelajaran drama yang berbasis kearifan lokal dilakukan dengan mengintegrasikan dua unsur utama yakni kearifan lokal dan nilai pendidikan karakter ke dalam pembelajaran yang terdokumentasi ke dalam kontrak kuliah, RPPS, silabus, dan evaluasi penilaian pembelajaran. Selanjutnya, penerapan pembelajaran drama yang berbasis kearifan lokal tercermin melalui proses pembelajaran. Unsur kearifan lokal khususnya kearifan lokal di wilayah Blitar diintegrasikan ke dalam proses pembelajaran drama. Unsur kearifan lokal tersebut meliputi unsur budaya, cerita rakyat, dan kesenian daerah. Pengintegrasian unsur kearifan lokal ke dalam pembelajaran tersebut juga digunakan sebagai penguatan pendidikan karakter pada mahasiswa.
\end{abstract}

Kata Kunci: kearifan lokal, pembelajaran drama, penguatan karakter diri.

\begin{abstract}
This research describes the strengthening of self character through learning based on local wisdom of the students, focusing on (1) learning design and (2) the application of local wisdombased drama learning to strengthen the character in the students. This research belongs to qualitative descriptive research. The result of this research is the design of learning based on local wisdom drama is done by integrating two main elements of local wisdom and the value of character education into learning that is documented into lecture contract, RPPS, syllabus, and evaluation of learning appraisal. Furthermore, the application of learning based on local wisdom is reflected through the learning process. Elements of local wisdom, especially local wisdom in the region of Blitar is integrated into the learning process of drama. The elements of local wisdom include elements of culture, folklore, and local arts. The integration of local wisdom elements into the learning is also used as a strengthening of character education for students.
\end{abstract}

Keywords: local wisdom, drama learning, strengthening of self character.

\section{PENDAHULUAN}

Pembentukan karakter diri dilakukan melalui suatu proses yang sistematis dan berkesinambungan. Karakter diri yang kuat pada seseorang, khususnya mahasiswa memiliki pengaruh yang besar dalam menciptakan tatanan kehidupan sosial yang baik. Dalam setiap proses pendidikan harus ditanamkan nilai pendidikan karakter di dalamnya. Penguatan karakter diri pada seseorang memiliki manfaat yang penting. Dengan memiliki karakter yang baik, 
JIP, Vol.8, No. 1, Edisi Januari 2018, Hal: 40-52

Sabitul Kirom

seseorang akan berperilaku baik dan bermanfaat bagi lingkungannya. Lickona (2012:22) menjelaskan bahwa tanpa adanya nilai kebaikan dalam pembentukan karakter diri, seseorang tidak dapat hidup dengan bahagia. Tanpa karakter diri yang baik, manusia tidak akan mampu mewujudkan tatanan masyarakat yang menjunjung tinggi martabat seseorang.

Pendidikan pada dasarnya tidak hanya bertujuan membentuk seseorang menjadi insan yang cerdas, tetapi juga harus mampu mewujudkan seseorang yang berbudi luhur. Pendidikan karakter adalah wujud implementasi nyata yang sesuai dengan pandangan tersebut. Pendidikan karakter diharapkan dapat menjadi solusi untuk mengatasi persoalan yang berkaitan dengan krisis karakter bangsa. Pendidikan karakter juga berpengaruh positif terhadap kualitas akademik peserta didik (Wibowo, 2012:19).

Pendidikan karakter dapat diterapkan melalui berbagai media, salah satunya adalah karya sastra. Melalui media sastra, pendidikan karakter dapat diwujudkan dalam berbagai bentuk, mulai dari narasi hingga pertunjukan drama. Dalam menyajikan media sastra untuk penanaman nilai pendidikan karakter, perlu dipertimbangkan segi estetisnya, mulai dari segi bahasa hingga struktur cerita. Melalui sastra, berbagai wujud cerita yang mencerminkan nilai pendidikan karakter akan tercipta. Berbagai peristiwa yang di dalamnya mengandung unsur nilai karakter akan terlukiskan di dalam cerita, misalnya nilai kejujuran, toleransi, dan percaya diri.

Drama berasal dari bahasa Yunani yaitu "Dromai" yang bermakna bertindak, bereaksi, berbuat, atau berlaku. Berdasarkan makna tersebut, drama memiliki arti suatu perbuatan, tidakan, bereaksi. Saat ini, drama memiliki makna yang luas. Drama dapat dikategorikan ke dalam genre sastra dan genre kesenian yang berdiri sendiri. Teks drama memiliki kedudukan yang sama dengan puisi dan prosa sehingga dikategorikan sebagai salah satu genre sastra. Selanjutnya, pementasan drama merupakan gabungan dari bermacam jenis kesenian, misalnya seni musik, seni lukis, seni rias, tata lampu, dan sebagainya sehingga dapat dikategorikan sebagai salah satu kesenian yang mandiri (Waluyo, 2001: 2).

Penguatan nilai karakter pada mahasiswa tidak cukup hanya dengan pembelajaran yang bersifat teoritis yang dilakukan di kelas. Penguatan nilai karakter tersebut perlu dioptimalkan melalui proses pembiasaan. Pembelajaran drama merupakan salah satu media yang dapat 
JIP, Vol.8, No. 1, Edisi Januari 2018, Hal: 40-52

Sabitul Kirom

digunakan untuk proses pembiasaan penguatan nilai karakter tersebut. Melalui pembelajaran drama, penguatan nilai karakter, khususnya bagi mahasiswa dapat terwujud.

Drama memiliki keterkaitan dengan penanaman pendidikan karakter. Keterkaitan tersebut terwujud melalui manfaat drama yang dapat digunakan sebagai media untuk mengembangkan pendidikan watak atau karakter peserta didik. Drama juga mampu memperkenalkan berbagai fenomena kehidupan, misalnya keberhasilan, kebahagiaan, cinta, bahkan kehancuran. Dalam pengembangan karakter, drama mampu mengembangkan kepribadian yang kompleks, di antaranya imanjinasi, ketegaran, dan kreativitas (Endraswara, 2005: 192).

Pembelajaran tentang drama merupakan salah satu wujud apresiasi drama. Efendi (2002:3) mengungkapkan bahwa apresiasi drama merupakan aktivitas membaca, menonton, memahami, atau menghargai suatu drama. Melalui kegiatan apresiasi drama, seseorang diharapkan dapat memahami karakter tokoh di dalam drama tersebut. Dengan pemahaman yang mendalam, seseorang dapat mengambil berbagai hal positif, misalnya tentang karakter tokoh, motovasi, dan nilai postif yang ada di dalam drama tersebut.

Kegiatan apresiasi drama dapat diklasifikasikan menjadi dua, yaitu (1) kegiatan apresiasi drama secara reseptif dan (2) kegiatan apresiasi drama secara produktif. Kegiatan apresiasi drama secara reseptif lebih terfokus pada pemahaman dan penghayatan suatu karya drama. Kegiatan apresisasi drama secara produktif lebih menekankan pada pemahaman dan pemberian tanggapan terhadap suatu karya drama. Lebih jauh lagi, kegiatan apresiasi drama secara produktif juga dapat berupa kegiatan pementasan drama (Efendi, 2002:13).

Kearifan lokal yang terdapat di setiap daerah harus terus dikembangkan. Asriati (2012:111) menjelaskan bahwa kearifan lokal merupakan suatu gagasan yang tumbuh dan berkembang di masyarakat yang berkaitan dengan berbagai hal yang bersifat sakral maupun kehidupan yang bersifat biasa saja. Wujud kearifan lokal yang ada di masyarakat bisa berupa budaya, yakni berupa nilai, norma, hukum adat, etika, kepercayaan, dan adat istiadat. Nilai-nilai luhur yang berhubungan dengan kearifan lokal yaitu: (1) cinta kepada Tuhan, (2) tanggung jawab, mandiri, dan disiplin, (3) jujur, (4) santun dan hormat, (5) kasih 
JIP, Vol.8, No. 1, Edisi Januari 2018, Hal: 40-52

Sabitul Kirom

sayang, (6) kerja keras, percaya diri, dan pantang menyerah, (7) kepemimpinan dan keadilan, (8) rendah hati, (9) toleransi, persatuan, dan cinta damai.

Upaya pengembangan kearifan lokal dapat dilakukan melalui pendidikan. Pendidikan berbasis kearifan lokal merupakan upaya yang dilakukan secara terencana melalui penggalian potensi suatu daerah tertentu sebagai usaha dalam menciptakan proses pembelajaran supaya peserta didik mampu mengembangkan potensinya dalam membangun bangsa dan negara. Proses pengembangan kearifan lokal dalam pendidikan tersebut dapat diimplementasikan melalui pembejaran drama di kampus. Pembelajaran drama berbasis kearifan dapat diwujudkan melalui proses pembelajaran yang di dalamnya mengandung unsur kearifan lokal, misalnya seni dan budaya daerah tertentu.

Pembelajaran drama berbasis kearifan lokal dapat digunakan sebagai upaya untuk membentuk karakter mahasiswa yang berkualitas. Penguatan karakter diri pada mahasiswa penting dilakukan sebagai upaya mempersiapkan generasi masa depan yang unggul dan berkembang. Mahasiswa merupakan generasi masa depan yang akan terjun langsung dalam kehidupan di masyarakat. Melalui pendidikan, upaya pengembangan seluruh potensi yang dimiliki oleh mahasiswa dapat dilakukan. Proses pendidikan yang di dalamnya mengandung unsur penguatan karakter diri merupakan upaya nyata dalam mewariskan dan mengembangkan budaya dan karakter bangsa kepada generasi muda. Proses pendidikan tersebut pada akhirnya akan meningkatkan kualitas masyarakat di masa depan.

Penguatan nilai karakter bagi mahasiswa harus terus ditingkatkan. Pendidikan yang berorientasi pada penguatan nilai karakter akan mampu mewujudkan tujuan penanaman nilai karakter sesuai dengan yang dicanangkan pemerintah. Terdapat empat hal pokok yang menjadi tujuan pelaksanaan pendidikan karakter. Pertama, pendidikan karakter bertujuan untuk mengembangkan aspek afektif individu. Kedua, pendidikan karakter bertujuan untuk menanamkan perilaku yang terpuji sesuai dengan nilai universal dan budaya bangsa yang religius. Ketiga, pendidikan karakter bertujuan untuk penanaman jiwa kepemimpinan dan rasa tanggung jawab. Keempat, pendidikan karakter bertujuan untuk pengembangan sikap mandiri, kreatif, dan berwawasan kebangsaan yang baik. Kelima, pendidikan karakter bertujuan untuk mewujudkan 
JIP, Vol.8, No. 1, Edisi Januari 2018, Hal: 40-52

Sabitul Kirom

lembaga pendidikan menjadi tempat yang menyenangkan, aman, penuh persahabatan dan kekuatan sebagai tempat belajar (Kemendiknas, 2010:7).

Nilai karakter pada penelitian ini difokuskan pada delapan belas nilai karakter sesuai dengan yang dipaparkan oleh Pemerintah. Kemendiknas (2010:9-10) memaparkan bahwa pengembangan nilai pendidikan karakter tersebut didasarkan pada empat hal pokok, yaitu (1) agama, (2) pancasila, (3) budaya, dan (4) tujuan pendidikan. Berdasarkan empat hal pokok tersebut, ditetapkanlah delapan belas nilai pendidikan karakter, yakni (1) religius, (2) jujur, (3) toleransi, (4) disiplin, (5) kerja keras, (6) kreatif, (7) mandiri, (8) demokratis, (9) rasa ingin tahu, (10) semangat kebangsaan, (11) cinta tanah air, menghargai prestasi, bersahabat/komunikatif, (14) cinta damai, (15) gemar membaca, (16) peduli lingkungan, (17) peduli sosial, dan (18) tanggung jawab.

Penelitian yang berkaitan dengan penguatan karakter melalui pembelajaran drama berbasis kearifan lokal pada mahasiswa belum banyak dilakukan. Penelitian yang banyak dilakukan yaitu berkaitan dengan pembelajaran sastra sebagai media penanaman nilai pendidikan karakter di tingkat sekolah, mulai dari SD, SMP, dan SMA. Penelitian yang sudah pernah dilakukan dan relevan dengan penelitian ini sebagai berikut. Pertama, penelitian yang dilakukan oleh Rosala (2016) yang berjudul "Pembelajaran Seni Budaya Berbasis Kearifan Lokal dalam Upaya Membangun Pendidikan Karakter Siswa di Sekolah Dasar". Hasil dari penelitian tersebut yaitu (1) pendidikan seni budaya berbasis kearifan lokal bisa digunakan untuk membangun karakter bangsa, (2) pembelajaran seni budaya dapat dipadukan dengan pembelajaran berbasis kearifan lokal. Pembelajaran seni budaya berbasis kearifan lokal dapat diterapkan untuk menanamkan pendidikan karakter pada siswa di Sekolah Dasar. Kedua, penelitian yang dilakukan oleh Sumayana (2017) dengan judul "Pembelajaran Sastra di Sekolah Dasar Berbasis Kearifan Lokal (Cerita Rakyat)". Hasil dari penelitian tersebut yaitu pembelajaran sastra di Sekolah Dasar harus dapat memotovasi siswa supaya aktif dalam pembelajaran. Upaya yang dapat dilakukan oleh guru yaitu dengan memadukan antara cerita rakyat dengan kearifan lokal. Pembelajaran sastra yang berbasis kearifan lokal dapat dilakukan di dalam kelas dan di luar kelas. 
JIP, Vol.8, No. 1, Edisi Januari 2018, Hal: 40-52

Sabitul Kirom

Kedua penelitian tersebut memiliki persamaan dan perbedaan dengan penelitian ini. Persamaan antara kedua penelitian tersebut dengan penelitian ini yaitu samasama membahas tentang pembelajaran yang bermuatan kearifan lokal untuk membangun pendidikan karakter. Perbedaan antara penelitian tersebut dengan penelitian ini terletak pada media penguatan nilai pendidikan karakter. Pada penelitian ini, penguatan nilai pendidikan karakter dilakukan melalui pembelajaran drama, sedangkan dalam penelitian yang sudah dilakukan penanaman nilai pendidikan karakter melalui pembelajaran sastra dan seni budaya. Perbedaan lainnya yaitu terletak pada subjek penelitian. Pada penelitian ini, penelitian dilakukan pada mahasiswa, sedangkan dua penelitian yang sudah dilakukan tersebut penelitian dilakukan pada siswa Sekolah Dasar. Penelitian ini dilakukan sebagai upaya untuk memperkaya penelitian tentang pembelajaran drama yang berbasis kearifan lokal sebagai sarana memperkuat karakter peserta didik.

Berdasarkan paparan tersebut, permasalahan yang menjadi fokus dalam penelitian ini berkaitan dengan pembelajaran drama yang berbasis kearifan lokal sebagai media penguatan karakter pada mahasiswa.
Fokus penelitian yang pertama berkaitan dengan perancangan pembelajaran drama yang berbasis kearifan lokal sebagai media penguatan karakter pada mahasiswa. Fokus penelitian yang kedua berkaitan dengan penerapan pembelajaran drama yang berbasis kearifan lokal sebagai media penguatan karakter pada mahasiswa.

\section{METODE PENELITIAN}

Penelitian ini menggunakan metode penelitian kualitatif dengan desain penelitian deskriptif kualitatif. Desain penelitian deskriptif kualitatif dipilih dengan didasarkan pada berbagai hal yakni (1) penelitian ini dilaksanakan pada latar alamiah, yaitu proses pembelajaran drama di kampus; (2) manusia (peneliti) dijadikan instrumen utama; dan (3) penelitian ini lebih mengutamakan proses selama penelitian daripada hasil. Penelitian ini dilakukan di kota Blitar, tepatnya di Program Studi S1 Pendidikan Guru Sekolah Dasar (PGSD) Universitas Islam Balitar (Unisba) Blitar. Penelitian ini dilakukan selama tiga bulan, yakni mulai bulan November tahun 2017 hingga Januari tahun 2018.

Instrumen penelitian yang digunakan untuk pengumpulan data yaitu lembar observasi, lembar wawancara, dan lembar pengamatan proses pembelajaran. Peneliti 
JIP, Vol.8, No. 1, Edisi Januari 2018, Hal: 40-52

Sabitul Kirom

secara langsung melakukan pengamatan terhadap proses pembelajaran drama yang berbasis kearifan lokal. Peneliti juga melakukan observasi di kelas dan wawancara secara langsung baik terhadap dosen maupun mahasiswa.

Hasil dari penelitian ini disajikan secara deskriptif kualitatif. Data yang digunakan dalam penelitian berupa data hasil observasi, wawancara, dan dokumentasi. Subjek dalam penelitian ini yaitu Dosen S1 PGSD Unisba Blitar dan mahasiswa S1 PGSD Unisba Blitar semester 5. Teknik pengumpulan data yang digunakan dalam penelitian ini meliputi dokumentasi, wawancara, dan observasi. Pengecekan keabsahan data dalam penelitian ini yaitu dengan triangulasi. Teknik analisis data yang digunakan dengan cara mereduksi data, penyajian data, dan penarikan simpulan.

\section{HASIL PENELITIAN DAN PEMBAHASAN}

\section{Hasil Penelitian}

Berdasarkan hasil analisis data yang diperoleh dari lokasi penelitian diperoleh hasil penelitian sebagai berikut. Pertama, hasil penelitian yang berkaitan dengan perancangan pembelajaran drama yang berbasis kearifan lokal sebagai media penguatan karakter pada mahasiswa. Kedua, hasil penelitian yang berkaitan dengan penerapan pembelajaran drama yang berbasis kearifan lokal sebagai media penguatan karakter pada mahasiswa. Hasil penelitian tersebut dijelaskan sebagai berikut.

\section{Perancangan Pembelajaran Drama yang} Berbasis Kearifan Lokal sebagai Media Penguatan Karakter pada Mahasiswa

Berdasarkan hasil analisis data diketahui bahwa dosen di Program Studi S1 PGSD Unisba Blitar telah melakukan perancangan pembelajaran drama yang berbasis kearifan lokal. Perancangan pembelajaran dilakukan oleh dosen dengan memperhatikan berbagai aspek, di antaranya aspek mahasiswa, aspek kearifan lokal, dan aspek penanaman nilai pendidikan karakter. Berbagai aspek tersebut dipadukan untuk memperoleh suatu proses pembelajaran yang nantinya dapat membentuk karakter mahasiswa yang unggul baik dari segi afektif, kognitif, dan psikomotorik.

Unsur kearifan lokal yang dimasukkan ke dalam perancangan pembelajaran disesuaikan dengan unsur kearifan lokal di wilayah Blitar. Unsur kearifan lokal di wilayah Blitar cukup banyak, mulai dari unsur budaya, kesenian, 
JIP, Vol.8, No. 1, Edisi Januari 2018, Hal: 40-52

Sabitul Kirom

dan cerita rakyat. Berbagai unsur kearifan lokal tersebut dimasukkan dalam pembelajaran. Selain unsur kearifan lokal, unsur pendidikan karakter juga diintegrasikan dalam perancangan proses pembelajaran. Perancangan tersebut selanjutnya diimplementasikan ke dalam kontrak kuliah, Rencana Pelaksanaan Pembelajaran Semester (RPPS), silabus, dan evaluasi penilaian pembelajaran.

Pembelajaran drama yang berbasis kearifan lokal dirancang dosen dengan menempatkan mahasiswa sebagai pusat pembelajaran. Pembelajaran tidak hanya sekadar teori, tetapi lebih menekankan pada praktik. Pembelajaran bukan merupakan kegiatan yang bersifat pasif, yakni mahasiswa hanya menerima materi dari dosen, tetapi lebih menekankan pada proses aktif. Proses aktif dalam pembelajaran drama yang dimaksud yaitu selama proses pembelajaran mahasiswa diusahakan untuk menemukan berbagai pengalaman baru guna membentuk suatu makna. Makna tersebut tercipta berdasarkan berbagai hal yang dapat dilihat, didengar, dan dirasakan oleh mahasiswa. Peran dosen yang utama dalam pembelajaran adalah sebagai pihak yang mengatur, memfasilitasi, dan mengarahkan mahasiswa dalam membentuk sendiri pengetahuannya.
Penerapan Pembelajaran Drama yang Berbasis Kearifan Lokal sebagai Media Penguatan Karakter pada Mahasiswa

Berdasarkan hasil analisis data diketahui bahwa dosen di Program Studi S1 PGSD Unisba Blitar telah melakukan pembelajaran drama yang berbasis kearifan lokal sebagai media penguatan nilai pendidikan karakter pada mahasiswa. Dalam proses pembelajaran drama, dosen memasukkan unsur budaya, cerita rakyat, dan kesenian daerah di wilayah Blitar. Hal ini dilakukan sebagai upaya untuk mengembangkan unsur kearifan lokal di wilayah Blitar. Selain itu, pengintegrasian unsur kearifan lokal tersebut juga digunakan sebagai penguatan nilai karakter postif pada mahasiswa.

Selama proses pembelajaran, dosen telah mengimplementasikan nilai pendidikan karakter kepada mahasiswa. Model pembelajaran yang digunakan oleh dosen sangat variatif. Dosen menggunakan model pembelajaran yang memadukan antara model pembelajaran kontekstualisme dengan konstruktivisme. Selama proses pembelajaran mahasiswa ditekankan pada aspek aktif, kreatif, mandiri, dan menyenangkan. Model pembelajaran yang bersifat ceramah dan hanya berpusat pada 
JIP, Vol.8, No. 1, Edisi Januari 2018, Hal: 40-52

Sabitul Kirom

dosen dikurangi dan diganti dengan model pembelajaran yang berpusat pada mahasiswa.

Dalam proses pembelajaran drama, dosen membagi mahasiswa menjadi beberapa kelompok. Masing-masing kelompok anggotanya dibatasi maksimal lima orang. Tugas dari tiap kelompok tersebut yaitu menulis naskah drama sekaligus menampilkannya dalam sebuah pementasan. Tema yang dapat diangkat ke dalam naskah drama adalah tema-tema yang berkaitan dengan kearifan lokal di wilayah Blitar dan di dalamnya harus mengandung unsur nilai pendidikan karakter. Mahasiswa dapat mementaskan naskah drama yang sudah ditulis tersebut dalam dua model, yaitu mini drama atau operet. Pembatasan jumlah anggota kelompok tersebut dilakukan supaya mendapatkan hasil pembelajaran yang efektif, efisien, dan maksimal.

Pada saat pementasan drama yang dilakukan oleh masing-masing kelompok, terlihat unsur kearifan lokal muncul dari setiap kelompok. Ada kelompok yang mengangkat cerita rakyat yang ada di Blitar, yaitu cerita rakyat gong kyai pradah. Ada pula kelompok yang mengangkat kesenian daerah yaitu kesenian jaranan. Semua pementasan drama yang dilakukan oleh mahasiswa tersebut mengandung unsur nilai pendidikan karakter. Unsur nilai pendidikan karakter yang muncul tersebut di antaranya kejujuran, kerja keras, kedisiplinan, dan tanggung jawab.

\section{Pembahasan}

Pembahasan pada penelitian ini mencakup dua hal pokok. Pertama, pembahasan yang berkaitan dengan perancangan pembelajaran drama yang berbasis kearifan lokal. Kedua, pembahasan yang berkaitan dengan penerapan pembelajaran drama yang berbasis kearifan lokal sebagai media penguatan karakter pada mahasiswa.

Dosen merancang pembelajaran drama dengan memadukan dua unsur utama yakni kearifan lokal dan nilai pendidikan karakter. Unsur kearifan lokal yang dirancang disesuaikan dengan kearifan lokal di wilayah Blitar. Nilai pendidikan karakter ditanamkan kepada mahasiswa ketika proses pembelajaran drama berlangsung. Proses perancangan suatu pembelajaran sangatlah penting untuk mendapatkan kualitas pembelajaran yang optimal. Jamaludin (2003:9) menjelaskan bahwa pada dasarnya pembelajaran merupakan suatu proses yang sudah direncanakan oleh pendidik sehingga dapat tercipta keadaan yang kondusif bagi 
JIP, Vol.8, No. 1, Edisi Januari 2018, Hal: 40-52

Sabitul Kirom

peserta didik dalam melakukan kegiatan belajar. Proses belajar tersebut diarahkan pada serangkaian aktivitas yang bersifat fisik maupun mental pada peserta didik.

Unsur kearifan lokal sangat penting dimasukkan dalam perancangan pembelajaran. Hal ini karena kearifan lokal menyangkut gagasan-gagasan maupun kebiasaan yang bersifat lokal yang di dalamnya mengandung unsur kebaikan, bijaksana, kearifan, dan telah diikuti oleh masyarakat tersebut. Dengan memasukkan unsur kearifan lokal dalam sebuah pembelajaran maka akan dapat menjaga dan memelihara unsur kearifan lokal tersebut supaya tidak hilang.

Pendidikan merupakan sarana yang efektif dalam melestarikan kearifan lokal suatu daerah. Melalui pendidikan, unsur kearifan lokal tersebut dapat diimplementasikan secara langsung sehingga mahasiswa akan mengetahui berbagai kearifan lokal yang ada di suatu daerah. Dengan demikian, unsur budaya maupun kesenian yang menjadi salah satu wujud kearifan lokal suatu daerah akan tetap terjaga dan berkembang.

Pendidikan juga menjadi media yang efektif untuk penanaman nilai pendidikan karakter bagi mahasiswa. Melalui proses pembelajaran, khususnya pembelajaran drama nilai pendidikan karakter dapat ditanamkan kepada mahasiswa. Selain penananaman nilai pendidikan karakter, pembelajaran drama juga mengajarkan berbagai aspek mulai dari aspek kognitif, afektif, dan psikomotorik pada mahasiswa. Waluyo (2001:167) menjelaskan bahwa pada pembelajaran drama khususnya yang berkaitan dengan pementasan, kemampuan yang diajarkan tidak hanya aspek psikomotorik tetapi juga aspek kognitif dan afektif. Selanjutnya, berkaitan dengan proses berakting drama maka akan terjadi proses penyatuan antara aspek kognitif, afektif, dan psikomotorik.

Selanjutnya, pembahasan berkaitan dengan penerapan pembelajaran drama yang berbasis kearifan lokal sebagai media penguatan karakter pada mahasiswa. Dalam proses pembelajaran drama, dosen mengintegrasikan berbagai kearifan lokal dalam pebelajaran. Kearifan lokal tersebut khususnya yang berada di wilayah Blitar, yakni berupa budaya, cerita rakyat, dan kesenian. Pembelajaran drama yang dilakukan oleh dosen tidak hanya bersifat teoritis saja tetapi lebih banyak praktik langsung. Waluyo

(2001:161) mengungkapkan bahwa dalam pembelajaran drama tidak cukup hanya mengajarkan halhal yang berkaitan dengan pengetahuan 
JIP, Vol.8, No. 1, Edisi Januari 2018, Hal: 40-52

Sabitul Kirom

drama saja, tetapi juga harus mengajarkan materi apresiasi dan pementasan. Pembelajaran drama dikategorikan berhasil jika pembelajaran tersebut telah sesuai dengan teori Bloom yakni tujuan pembelajaran meliputi aspek kognitif, afektif, dan psikomotorik. Aspek kognitif meliputi pengetahuan, pemahaman, penerapan, analisis, sintesis, dan evaluasi. Aspek afektif meliputi menerima, mengahargai, menanggapi, mengorganisasi, dan mengarakterisasi nilai. Aspek psikomotorik meliputi persepsi, respon, mekanisme, kesiapan terpimpin, dan respon yang kompleks.

Drama merupakan salah satu bentuk sastra yang cukup diminati oleh mahasiswa sehingga implementasi dan penguatan nilai karakter selama proses pembelajaran lebih mudah. Pembelajaran drama menarik karena di dalamnya berkaitan erat dengan fenomena yang terjadi di kehidupan sekitar. Kosasih (2008:81) menjelaskan bahwa drama merupakan salah satu wujud karya sastra yang memiliki tujuan untuk mendeskripsikan kehidupan melalui berbagai pertikaian dan emosi yang diwujudkan dalam lakuan dan dialog. Lakuan dan dialog yang dilakukan dalam drama memiliki wujud yang mirip dengan yang terjadi dalam keseharian. Oleh karena itu, mahasiswa umumnya antusias dalam mengikuti proses pembelajaran.

Pembelajaran drama akan maksimal jika setiap mahasiswa mengikuti tahapantahapan proses pembelajaran. Abidin (2012:3) memaparkan bahwa pembelajaran merupakan suatu proses yang dilakukan guru/dosen supaya peserta didik belajar. Dari segi peserta didik, pembelajaran adalah suatu proses yang di dalamnya mengandung serangkaian aktivitas guna mencapai hasil belajar yang telah ditentukan. Pembelajaran merupakan suatu proses yang dilakukan oleh peserta didik untuk mencapai tujuan tertentu melalui proses pembimbingan, pengarahan, dan pemberian motivasi dari guru/dosen. Berdasarkan penjelasan tersebut, jelas bahwa mahasiswa harus mengikuti setiap proses dalam pembelajaran drama supaya tujuan akhir dari pembelajaran tersebut dapat dicapai.

Pembelajaran sastra, khususnya pembelajaran drama memiliki keterkaitan yang positif dalam penguatan karakter diri seseorang. Pembelajaran sastra umumnya membahas mengenai hal-hal yang berkaitan dengan nilai kehidupan. Sastra yang telah diintegrasikan dalam pembelajaran berperan dalam pengembangan aspek afektif, kognitif, dan psikomotorik. Selain itu, sastra juga mampu membentuk pola kepribadian 
JIP, Vol.8, No. 1, Edisi Januari 2018, Hal: 40-52

Sabitul Kirom

dan aspek sosial pada seseorang (Wibowo, 2013:19).

Pembelajaran drama memiliki kaitan erat dalam penanaman karakter pada diri seseorang. Menurut Endraswara (2005:192), drama mampu mengembangkan berbagai nilai karakter positif dalam diri peserta didik. Drama juga mampu menggambarkan fenomena kehidupan, mulai dari kebahagiaan, kepuasan, keberhasilan, cinta, kehancuran, dan kematian. Drama mampu berkontribusi dalam pengembangan kepribadian seseorang, misalnya imajinasi, kreativitas, dan ketegaran hati.

Berkaitan dengan proses pembelajaran drama dapat disimpulkan bahwa dosen Program Studi S1 PGSD Unisba Blitar telah mengimplementasikan nilai pendidikan karakter melalui pembelajaran drama. Dosen juga mengintegrasikan kearifan lokal, khususnya yang ada di wilayah Blitar ke dalam pembelajaran. Dosen merancang setiap pertemuan dengan model pembelajaran yang memperkuat karakter diri mahasiswa. Implementasi nilai karakter seperti kejujuran, kerja keras, kedisiplinan, dan tanggung jawab tercermin melalui berbagai kegiatan selama proses pembelajaran.

\section{SIMPULAN}

Berdasarkan temuan penelitian, analisis data, dan pembahasan terhadap pelaksanaan pembelajaran drama di Program Studi S1 PGSD Universitas Islam Balitar, maka dapat disimpulkan sebagai berikut.

Pertama, dosen melakukan perancangan pembelajaran drama dengan mengintegrasikan dua unsur utama yakni kearifan lokal dan nilai pendidikan karakter. Unsur kearifan lokal yang dirancang disesuaikan dengan kearifan lokal yang ada di wilayah Blitar. Nilai pendidikan karakter yang ditanamkan kepada mahasiswa tercermin melalui proses pembelajaran drama. Proses perancangan pembejaran tersebut terdokumentasi ke dalam kontrak kuliah, RPPS, Silabus, dan evaluasi penilaian pembelajaran.

Kedua, penerapan pembelajaran drama yang berbasis kearifan lokal tercermin melalui proses pembelajaran. Dalam proses pembelajaran drama, dosen memasukkan unsur kearifan lokal khususnya kearifan lokal di wilayah Blitar. Unsur kearifan lokal tersebut yaitu budaya, cerita rakyat, dan kesenian daerah. Pengintegrasian unsur kearifan lokal ke dalam pembelajaran tersebut juga digunakan sebagai penguatan nilai karakter postif pada mahasiswa. 
JIP, Vol.8, No. 1, Edisi Januari 2018, Hal: 40-52

Sabitul Kirom

\section{DAFTAR PUSTAKA}

Abidin, Y. (2012). Pembelajaran Bahasa

Berbasis Pendidikan Karakter.

Bandung: PT. Refika Aditama.

Asriati, N. (2012). Mengembangkan

Karakter Peserta Didik Berbasis

Kearifan Lokal Melalui

Pembelajaran di Sekolah. Jurnal

Pendidikan Sosiologi dan

Humaniora. Vol. 3 No.2 pp. 106119.

Efendi, A. (2002). Diktat Kuliah Telaah

Drama. Yogyakarta: FBS UNY.

Endraswara, S. (2005). Metode dan Teori

Pembelajaran Sastra. Yogyakarta:

Buana Pustaka.

Jamaludin. (2003). Problematik

Pembelajaran Bahasa dan Sastra.

Yogyakarta: Adicita Karya Nusa.

Kemendiknas. (2010). Bahan Pelatihan

Penguatan Metodologi

Pembelajaran Berdasarkan Nilai-

nilai Budaya untuk Membentuk Daya

Saing dan Karakter Bangsa. Jakarta:

Kementerian Pendidikan Nasional

Badan Penelitian dan Pengembangan

Pusat Kurikulum.

Kosasih, E. (2008). Apresiasi Prosa.

Jakarta: Nobel Edumedia.
Lickona, T. (2012). Character Matters

(Persoalan Karakter): Bagaimana Membantu Anak Mengembangkan

Penilaian yang Baik, Integritas, dan Kebajikan Penting Lainnya.

Diterjemahkan oleh Juma Abdu Wamaungo dan Jean Antunes Rudolf Zien. Jakarta: PT Bumi Aksara.

Rosala, D. (2016). Pembelajaran Seni Budaya Berbasis Kearifan Lokal dalam Upaya Membangun

Pendidikan Karakter Siswa di Sekolah Dasar. Jurnal Ritme. Vol. 2 No. 1. pp. 17-26.

Sumayana, Y. (2017). Pembelajaran Sastra di Sekolah Dasar Berbasis Kearifan Lokal (Cerita Rakyat). Jurnal Mimbar Sekolah Dasar. Vol 4 (1). pp. 21-28.

Waluyo, Herman J. (2001). Drama "Teori Pembelajarannya”. Yogyakarta: PT. Hanindita Graha Widya Yogyakarta.

Wibowo, A. (2012). Pendidikan Karakter: Strategi Membangun Karakter Bangsa Berperadaban. Yogyakarta: Pustaka Pelajar.

Wibowo, A. (2013). Pendidikan Karakter Berbasis Sastra. Yogyakarta: Pustaka Pelajar. 